\title{
Synthesis of geopolymer binders and mortars from Ijero-Ekiti calcined clay, blast furnace slag and river sand
}

\author{
Funmilayo I. Adeniyi ${ }^{1}$ and Mary B. Ogundiran ${ }^{2}$ \\ ${ }^{1}$ Analytical/Environmental Unit, Department of Chemistry, University of Ibadan, Nigeria \\ e-mail: fiadeniyi@gmail.com \\ ${ }^{2}$ Analytical/Environmental Unit, Department of Chemistry, University of Ibadan, Nigeria
}

\begin{abstract}
Geopolymer, an inorganic polymer is a greener alternative to Portland cement because of less $\mathrm{CO}_{2}$ emissions generated during its synthesis. Main precursors needed for its formation is silica and alumina. Geopolymer source materials are primarily fly ash, blast furnace slag, calcined kaolin clays. Ijero-Ekiti kaolin clay that is rich in silica and alumina is relatively abundant in Nigeria. Hence, the aim of this study was to develop geopolymer binder and mortars using Ijero-Ekiti calcined clay, blast furnace slag and river sand. Chemical and structural characterisation of source materials was determined. Geopolymer binders were synthesised at varying proportions of clay and BFS. The binder that gave the optimum compressive strength was used to prepare geopolymer mortars with sand at varying mix ratios with $8 \mathrm{M} \mathrm{NaOH} / \mathrm{NaSi}_{2} \mathrm{O}_{3}$ solution at ambient temperature. Mechanical, structural and durability properties of the geopolymer products were investigated.

FTIR spectrum of Ijero-Ekiti calcined clay showed a disappearance of surface $\mathrm{OH}$ groups when compared to its raw clay, confirming the transformation of kaolinite to metakaolinite. The calcined clay was composed mainly of silicon oxide and aluminium oxide. Si-O stretching vibration decreased as the BFS content increased in the binders. The water absorption values substantiated the low porosity of the binders. The geopolymer mortars compressive strength was in accordance with ASTM standard.
\end{abstract}

\section{Received: February 24, 2020; Accepted: April 6, 2020}

Keywords and phrases: Ijero-Ekiti clay, BFS, geopolymer binders, geopolymer mortars.

Copyright () 2020 Funmilayo I. Adeniyi and Mary B. Ogundiran. This is an open access article distributed under the Creative Commons Attribution License, which permits unrestricted use, distribution, and reproduction in any medium, provided the original work is properly cited. 
The results confirmed the suitability of Ijero-Ekiti calcined clay as a geopolymer precursor and its combination with blast furnace slag can be used as a greener alternative to Portland cement.

\subsection{Introduction}

Binders and mortars are important ingredients in building and construction works. The most common binder/cement used worldwide is Ordinary Portland cement. Common Cement mortars are paste made from Portland cement, sand and water. However, environmental issues of Ordinary Portland Cement (OPC) production are a major concern to the 21 st century world. OPC manufacturing process emits a total of $80 \%$ carbon dioxide per $1 \mathrm{~kg}$ of OPC [1]. Carbon dioxide $\left(\mathrm{CO}_{2}\right)$ and a host of other green house gases such as nitrous oxide (NOx), sulphur dioxide $\left(\mathrm{SO}_{2}\right)$ are responsible for changes in the world climate through global warming [1,2]. Efforts to reduce the use of OPC led to the utilisation of geopolymers, a greener alternative in the construction industry.

Geopolymers are amorphous to semi-crystalline aluminosilicate based inorganic polymers [3, 4 and 1]. They are formed by the dissolution and polycondensation of silica and alumina containing materials with alkaline silicate (i.e. $\mathrm{Na}, \mathrm{K}$ silicate) solutions at ambient temperature. The geopolymer 3-dimension structure made of silicon-oxoaluminate network consists of $\mathrm{SiO}_{4}$ and $\mathrm{AlO}_{4}$ monomers linked in an alternating sequence by even distribution of oxygen atoms. The negative charge of the $\mathrm{Al}^{3+}$ ions in $\mathrm{IV}$ - fold coordination is balanced by positive ions from the activating solution (i.e. $\mathrm{Na}^{+}$, $\mathrm{K}^{+}, \mathrm{Li}^{+}, \mathrm{Ba}^{2+}, \mathrm{Ca}^{2+}$ and $\mathrm{H}_{3} \mathrm{O}^{+}$) present in the geopolymer structure [3]. Geopolymer synthesis requires low energy input and its excellent properties include high early strength, high compressive strength, fire and chemical resistance [5].

Geopolymer source materials commonly researched on are calcined clay or metakaolin, blast furnace slag, fly-ash and rice husk ash. Metakaolin, calcined form of kaolin clay is a consistent material used in geopolymer research [6-11].

However, clay is a non-renewable material; its quarrying activities affect the aesthetics of the surrounding environment. Therefore replacement of calcined clay with blast furnace slag will be advantageous. Blast furnace slag is a by-product of pig iron manufacturing in Iron and Steel Industry [12-13]. Blast furnace slag exist in different 
forms but the most beneficial for geopolymerisation as source material, is ground granulated blast furnace slag, obtained by rapid cooling of slag with water [4, 13-14]. Blast furnace slag is composed mainly silicates of calcium, aluminium and magnesium [12-13]. Blast furnace slag has historically been used in blended form with Portland cement for construction purposes $[13,15-16]$ but has found greener applications in geopolymers [12, 17-18]. Geopolymerisation properties of binders and mortars based on metakaolin and blast furnace slag has been investigated. The effect of ground granulated blast furnace slag (GGBFS) on the microstructure and mechanical properties of metakaolinite based geopolymer binder, showed that the mechanical strength of the binder increased up to $20 \%$ GGBFS replacement [19]. The effect of substitution of ground granulated blast furnace slag (GGBFS) on the mechanical properties of metakaolin based geopolymer mortars for possible repair applications was investigated [20]. The geopolymer mortars were prepared by mixing MK and GGBFS with replacement of $0,5,10$ and $15 \%$ with $10,14,16$ and $18 \mathrm{M}$ sodium silicate and sodium hydroxide solution, while OPC mortars was prepared as control. The experiment showed the compressive strength, splitting tensile strength and flexural strength of the geopolymer mortars were higher compared to the OPC mortars. Furthermore, the effect of curing temperature on long term properties of silicate-activated ground granulated blast furnace slag (GGBFS) metakaolin (MK) binders was studied [21]. The binders were synthesised by mixing MK and GGBFS at replacement percentage of 0, 20, 50 and $100 \%$. The results showed that compressive strength increased when the geopolymers binders were cured at $20^{\circ} \mathrm{C}$. Additionally, the effect of silicate content on mechanical and durability properties of metakaolin (MK) and metakaolin/blast furnace slag alkaline activated mortars was investigated [22]. The microstructure of the metakaolin mortars was altered by the incorporation of blast furnace slag.

Previous studies on Ijero-Ekiti calcined clay based geopolymer focused on its characterisation and its possibility of reacting with ground waste window glass [23]. The positive venture of incorporating blast furnace slag in clay based geopolymer binders and mortars in this study will yield a material suitable for construction purposes at moderate compressive strength range. The chemical and structural composition of the geopolymer source materials was elucidated, the suitable mix ratios of source materials were optimised and their effects on compressive strength were investigated. 


\subsection{Materials and Methods}

\subsection{Raw materials}

The materials used in this study were Ijero-Ekiti kaolin clay, blast furnace slag, river sand and alkaline activator sodium hydroxide $(\mathrm{NaOH})$ and sodium silicate $\left(\mathrm{Na}_{2} \mathrm{SiO}_{3}\right)$ solution and distilled water. Ijero-Ekiti calcined clay; a thermally treated product of kaolin clay was obtained from clay deposit in Ijero local government, Ekiti state, Nigeria. The clay was calcined in a laboratory muffle furnace from ambient temperature to $700^{\circ} \mathrm{C}$ for 6 hours and sieved with $212 \mu \mathrm{m}$ mesh sieve. Blast furnace slag collected from a defunct Iron smelting industry in Delta state, Nigeria was oven dried at $105^{\circ} \mathrm{C}$ for 3 hours and sieved with $212 \mu \mathrm{m}$ mesh sieve. River sand was obtained locally in Ibadan, Nigeria, sun dried to reduce its moisture content and sieved with $600 \mu \mathrm{m}$ mesh size sieve. $8 \mathrm{M}$ sodium hydroxide $(\mathrm{NaOH})$ solution was prepared with distilled water. Chemical composition of sodium silicate $\left(\mathrm{Na}_{2} \mathrm{SiO}_{3}\right)$ solution was $30.1 \% \mathrm{SiO}_{2}, 9.4 \% \mathrm{Na}_{2} \mathrm{O}$ and $60.5 \% \mathrm{H} 2 \mathrm{O} .8 \mathrm{M} \mathrm{NaOH} / \mathrm{Na}_{2} \mathrm{SiO}_{3}$ solution was prepared 24 hours before use at a mixing ratio of $1: 1$.

\subsection{Materials characterisation}

Chemical composition of Ijero-Ekiti calcined clay (ICC) and river sand (RS) were determined with X-Ray fluorescence spectrometer (PAnalytical XRF machine PW2400) (Table 1). The particle size distribution of raw, calcined Ijero clay and blast furnace slag was determined using Dry sieve analysis and the results are presented in Table 2. The absorption spectra of raw and calcined Ijero clay, blast furnace slag and river sand were determined by $\mathrm{KBr}$ pellet method of Fourier Transform Infrared spectroscopy (PerkinElmer Fourier Transform Infrared Spectrum BX) and shown in Figures 1, 2 and 3.

\subsection{Synthesis of geopolymer binders and mortars}

Ijero-Ekiti calcined clay (ICC) and blast furnace slag (BFS) was mixed with 8M $\mathrm{NaOH} / \mathrm{Na}_{2} \mathrm{SiO}_{3}$ solution at varying ratios of 100:0, 75:25, 50:50 and 25:75. The geopolymer paste formed was cast in $29 \mathrm{~mm}$ by $29 \mathrm{~mm}$ cylindrical moulds and vibrated manually for 5 minutes for compaction and reduction of entrapped air. The moulds were covered and allowed to set at ambient temperature of $25^{\circ} \mathrm{C}$. The hardened geopolymer binders de-moulded after 3 days were cured in sealed plastic bags at ambient temperature to minimise the effect of evaporation. Compressive strength of the geopolymer binders at 
7, 14, 21 and 28 days were measured with an automatic compression test machine (ELE International). The values presented are the average of compressive strength results of two samples in $\mathrm{N} / \mathrm{mm}^{2}$. Mix ratio of geopolymer binder with the best compressive strength and river sand were used to synthesise geopolymers mortars at ratios of 75:25, 50:50 and 25:75. The bulk density of the geopolymer binders and mortars were measured at 28 days according to NEN 1170-6 specification. The height and diameter of the geopolymer binders and mortars was obtained using formula $\pi \mathrm{r}^{2} \mathrm{~h}$ and results expressed in $\mathrm{kg} / \mathrm{m}^{3}$. Water absorption capacity of the geopolymer samples was determined by weighing the synthesised geopolymer binders and mortars. They were immersed in distilled water for 1 hour and air dried for 1 hour at ambient temperature and reweighed to constant weight.

\subsection{Geopolymer characterisation}

The geopolymer reaction of each ratio of binders was stopped at 28 days with isopropyl alcohol, dried at $105^{\circ} \mathrm{C}$ for 6 hours to remove adsorbed water, crushed and sieved with $212 \mu \mathrm{m}$ mesh sieve. The structural change in the geopolymer binders were elucidated with Fourier Transform Infra Red (FTIR) spectroscopy.

\section{Results and Discussion}

\subsection{Source materials characterisation}

\subsubsection{X-Ray fluorescence analysis of source materials}

The results of the chemical composition of Ijero-Ekiti calcined clay, river sand and blast furnace slag are presented in Table 1. The clay has a combined percentage of $\mathrm{SiO}_{2}$, $\mathrm{Al}_{2} \mathrm{O}_{3}$ and $\mathrm{Fe}_{2} \mathrm{O}_{3}$ of $98.5 \%$. The chemical composition of river sand indicates its high silica content compared to calcined clay. The $\mathrm{CaO}$ content of the blast furnace slag with a value of $53.73 \%$ will be a source of calcium to the geopolymer products [19].

Table 1. Chemical composition of Ijero-Ekiti calcined clay, river sand and blast furnace slag.

\begin{tabular}{llllllllllll}
\hline Samples & $\mathrm{SiO}_{2}$ & $\mathrm{Al}_{2} \mathrm{O}_{3}$ & $\mathrm{Fe}_{2} \mathrm{O}_{3}$ & $\mathrm{CaO}$ & $\mathrm{MgO}$ & $\mathrm{SO}_{3}$ & $\mathrm{~K}_{2} \mathrm{O}$ & $\mathrm{TiO}_{2}$ & $\mathrm{Mn}_{2} \mathrm{O}_{3}$ & $\mathrm{Na}_{2} \mathrm{O}$ & $\mathrm{LOI}$ \\
\hline Calcined clay & 52.9 & 45.5 & 0.1 & 0.00 & 0.12 & 0.00 & 0.19 & 0.00 & 0.01 & 0.00 & 1.46 \\
River sand & 67.7 & 5.23 & 1.01 & 0.35 & 0.00 & 0.01 & 3.81 & 0.20 & 0.01 & 0.17 & 0.80 \\
Slag & 1.24 & 0.38 & 0.38 & 53.73 & 1.52 & 0.39 & 0.03 & 0.03 & 0.11 & 0.00 & - \\
\hline
\end{tabular}




\subsubsection{Particle size analysis}

The particle size distribution trend of raw, calcined Ijero-Ekiti clay and blast furnace slag is presented in Table 2. Percentage passing of calcined clay was higher than its raw form due to its high surface area, hence increasing its reactivity for geopolymerisation. The fine particle size of blast furnace slag will contribute to rapid geopolymerisation reaction.

Table 2. Particle size distribution of source materials

\begin{tabular}{cccc}
\hline \multicolumn{4}{c}{ Percentage passing $(\%)$} \\
\hline IS Sieve & Raw clay & Calcined clay & Blast furnace Slag \\
\hline $212 \mu \mathrm{m}$ & 100 & 100 & 100 \\
$150 \mu \mathrm{m}$ & 96.39 & 96.56 & 77.3 \\
$106 \mu \mathrm{m}$ & 48.89 & 88.56 & 22.2 \\
$63 \mu \mathrm{m}$ & 9.79 & 29.2 & 1.40 \\
Pan & 0.00 & 0.06 & 0.00 \\
\hline
\end{tabular}

\subsubsection{FTIR analysis of source materials}

Fourier Transform Infra Red (FTIR) spectra of the raw and calcined clays and blast furnace slag are presented in Figures 1-3. The surface $\mathrm{OH}$ bands with sharp peaks at $3652 \mathrm{~cm}^{-1}$ observed in raw Ijero-Ekiti clay, disappeared in calcined Ijero-Ekiti clay, confirming the transformation of kaolinite to metakaolinite [24]. The broad absorption centred on $3467 \mathrm{~cm}^{-1}$ in Figure 2 for calcined clay is attributed to adsorbed atmospheric water $[5,25]$.

$\mathrm{Si}-\mathrm{O}$ stretching vibration was observed at $1039 \mathrm{~cm}^{-1}$ in the raw clay and $1067 \mathrm{~cm}^{-1}$ in the calcined clay. The bands at $923 \mathrm{~cm}^{-1}$ in raw clay corresponding to Al-O-H stretching vibration were replaced with a lower wave number $808 \mathrm{~cm}^{-1}$ in calcined clay $[5,26]$.

The Si-O bending vibration observed at $660 \mathrm{~cm}^{-1}, 550 \mathrm{~m}^{-1}$ and $436 \mathrm{~cm}^{-1}$ in the raw clay and calcined clay at $662 \mathrm{~cm}^{-1}, 553 \mathrm{~cm}^{-1}$ and $439 \mathrm{~cm}^{-1}$ indicates the presence of quartz and confirms its stability after calcination of clay. The FTIR spectrum of the blast 
furnace slag is presented in Figure 3. Absorption band at $3630 \mathrm{~cm}^{-1}$ indicates surface $\mathrm{OH}$ groups, while that of $3445 \mathrm{~cm}^{-1}$ and $1790 \mathrm{~cm}^{-1}$ are due to stretching and bending vibrations of $\mathrm{OH}$ groups of water molecules in the slag [27-28]. A weak double peak at $2947 \mathrm{~cm}^{-1}$ and $2885 \mathrm{~cm}^{-1}$ is attributed to harmonics of carbon in calcite of blast furnace slag [27].

A broadened peak attributed to $\mathrm{C}-\mathrm{O}$ asymmetric stretching vibration of $\mathrm{CO}_{3}^{2-}$ molecules was observed at $1435 \mathrm{~cm}^{-1}$ and is due to the carbonation of slag exposed to the atmosphere [27, 29]. Absorption peaks at $1037 \mathrm{~cm}^{-1}$ indicates the presence of Si-O stretching vibration bands while $\mathrm{Si}-\mathrm{O}-\mathrm{Si}$ bending vibration bands was observed at $693 \mathrm{~cm}^{-1}$ (Sakulich et al. [27]). Absorption bands at $871 \mathrm{~cm}^{-1}$ correspond to asymmetric stretching vibration of $\mathrm{AlO}_{4}^{-}$groups present in the slag [29].

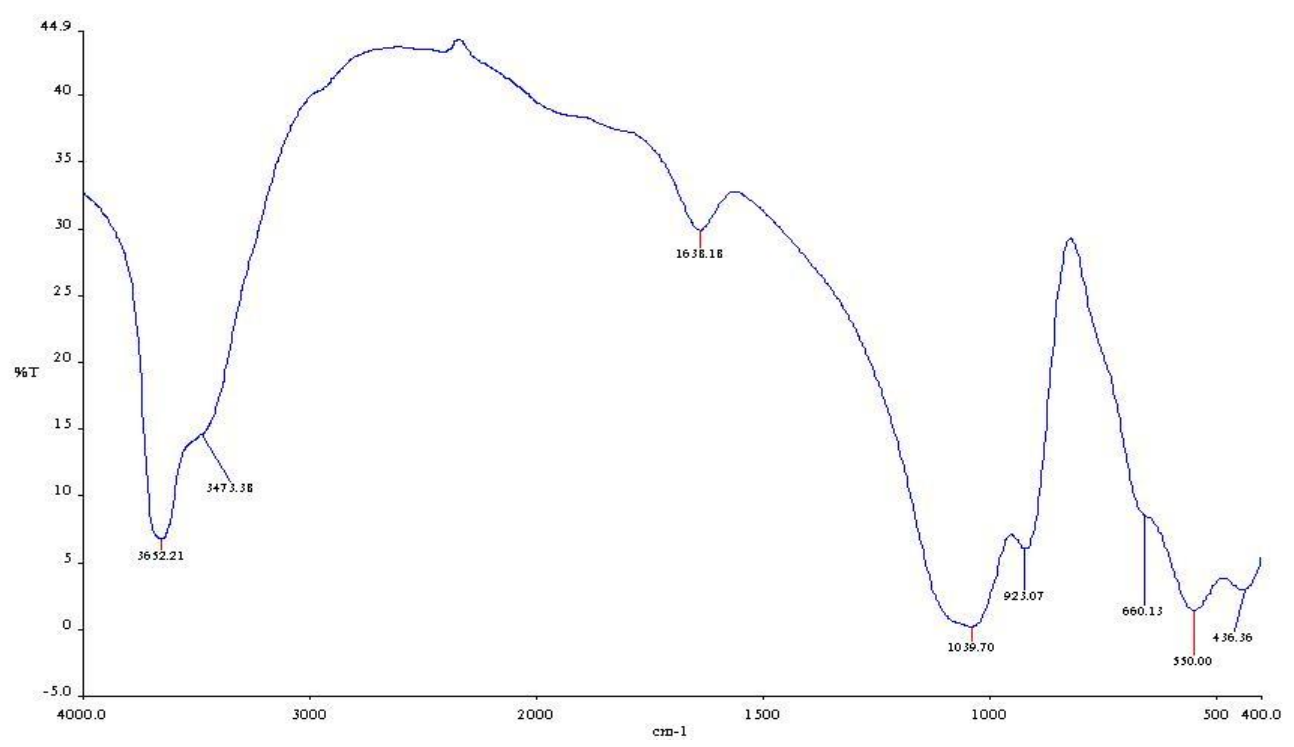

Figure 1. FTIR spectrum of raw Ijero-Ekiti kaolin clay [23]. 


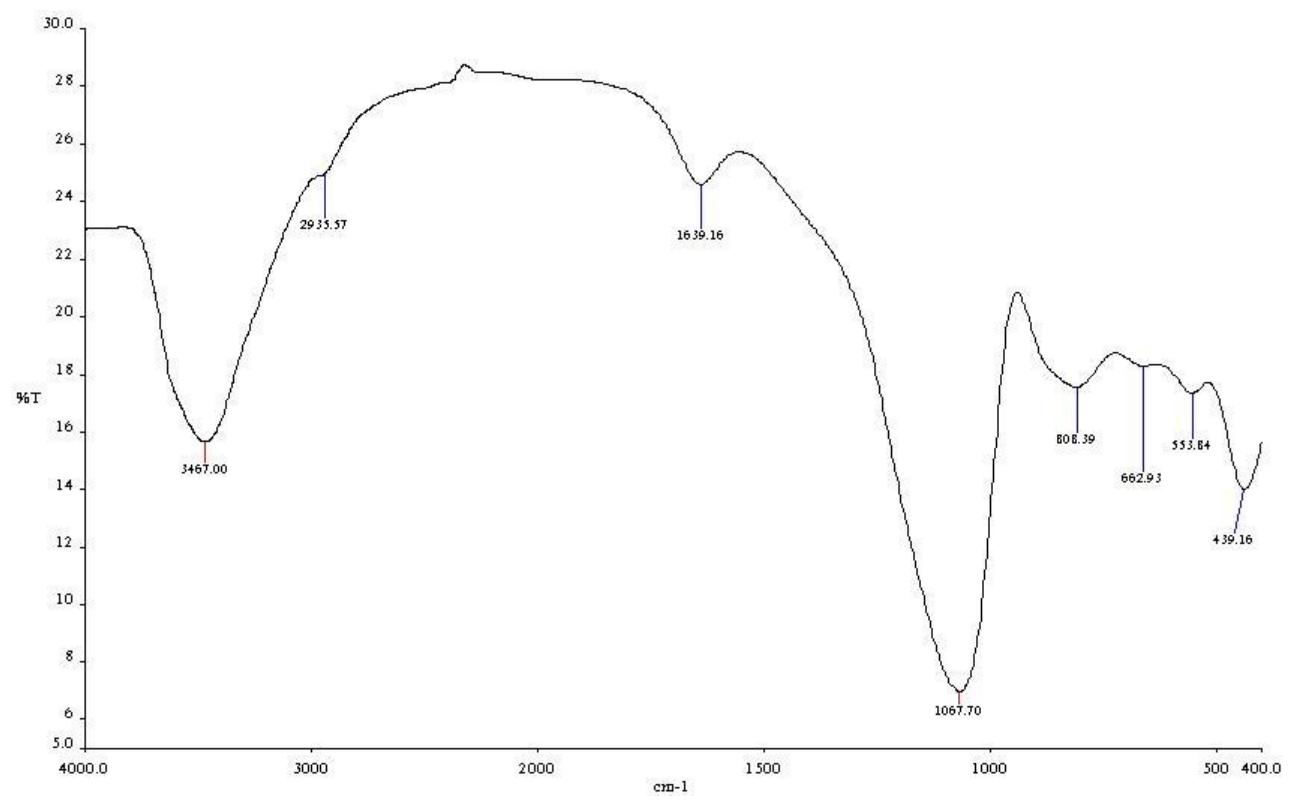

Figure 2. FTIR spectrum of Ijero-Ekiti calcined clay [23].

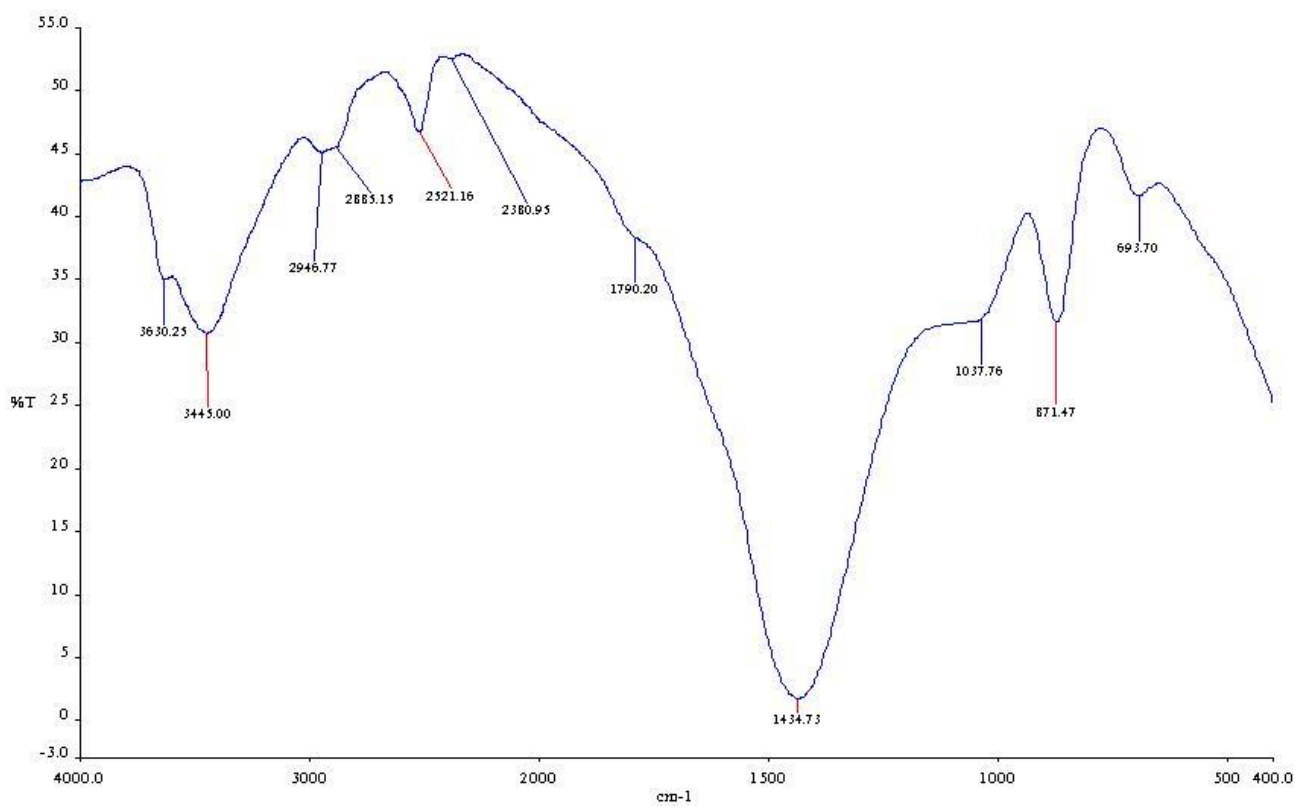

Figure 3. FTIR spectrum of blast furnace slag. 


\subsection{Geopolymer products characterisation}

\subsubsection{Compressive strength test}

The compressive strength values of geopolymer binders from mix ratios of calcined clay and blast furnace slag are presented in Figure 4.

The compressive strength of the geopolymer binders increased from $10.1 \pm 0.12$ to $15.8 \pm 0.54 \mathrm{~N} / \mathrm{mm}^{2}$ as the percentage of slag increased from $25 \%$ to $50 \%$ and $75 \%$ in the mixtures. The trend implied that the compressive strength increased as the slag content increased. $25 \%$ calcined clay and $75 \%$ slag geopolymer binder gave the highest compressive strength of $15.8 \pm 0.54 \mathrm{~N} / \mathrm{mm}^{2}$ at 28days, hence the mix ratio was used in producing geopolymer mortars with river sand. The increase in compressive strength of the calcined clay geopolymer binder is due to the inclusion of blast furnace slag. The result of the effect of river sand on the mechanical properties of Ijero-Ekiti calcined clay and slag geopolymer mortars at 7, 14, 21 and 28 days are presented in Figure 5.

Geopolymer mortar with $50 \%$ sand replacement gave the highest compressive strength of $18.7 \pm 0.32 \mathrm{~N} / \mathrm{mm}^{2}$ at 28 days, which indicates $50 \%$ replacement, gave the optimum strength for the geopolymer mortar. The geopolymer mortar with $75 \%$ sand replacement gave the lowest compressive strength implying that sand has a detrimental effect on the mortar at high percentage. This phenomenon may be due to the fact at high percent replacement; sand did not participate in the geopolymer reaction but was present as inactive filler [30].

The ASTM specifications for different types of bricks are presented in Table 5. The compressive strength at 28 days of geopolymer mortars for all mix ratios met the ASTM C34-17 [31] specification for production of load bearing wall tiles. Compressive strength of geopolymer mortars with mix ratios 50\% geopolymer binder and 50\% sand is lower than the limit of ASTM C62-17 [32] for building bricks in severe weathering (20.7MPa) but suitable for use in moderate and negligible weathering conditions. Additionally, the geopolymer mortars met the ASTM C216-17a [33] specification for facing brick in moderate weathering conditions. 


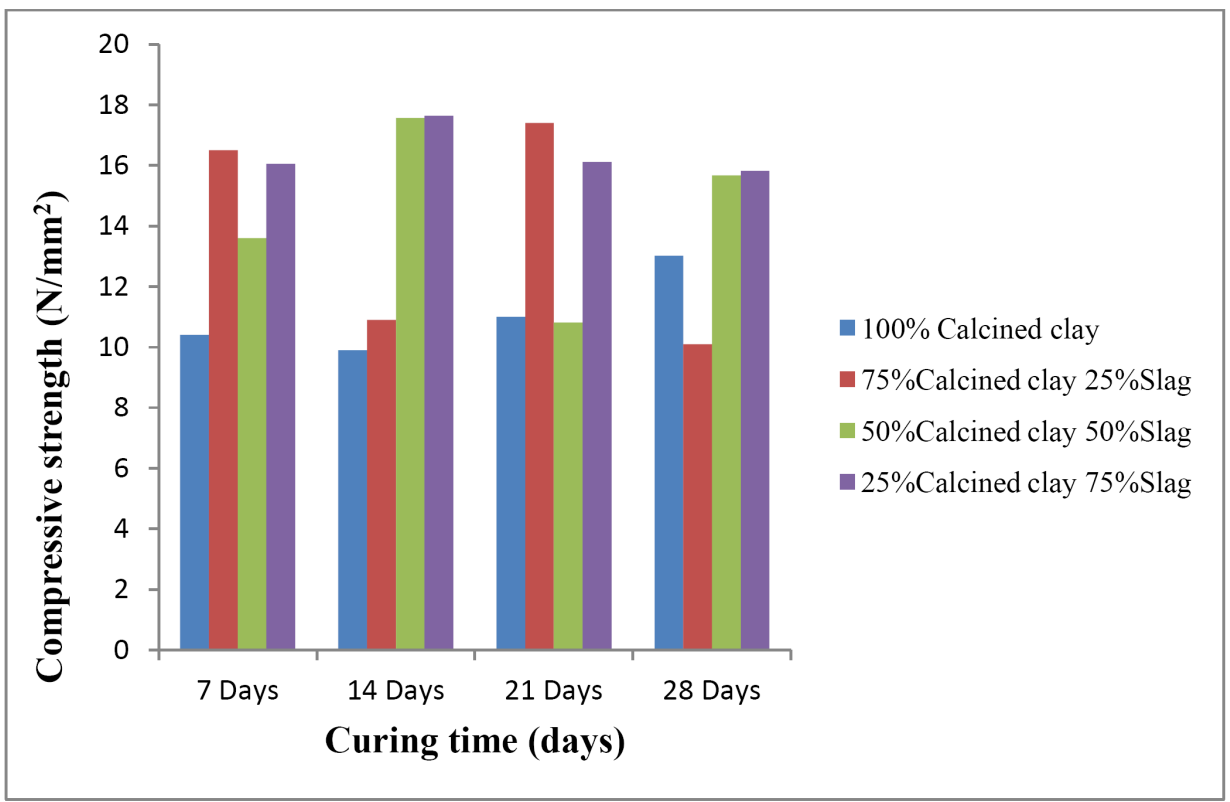

Figure 4. Compressive strength of geopolymer binders.

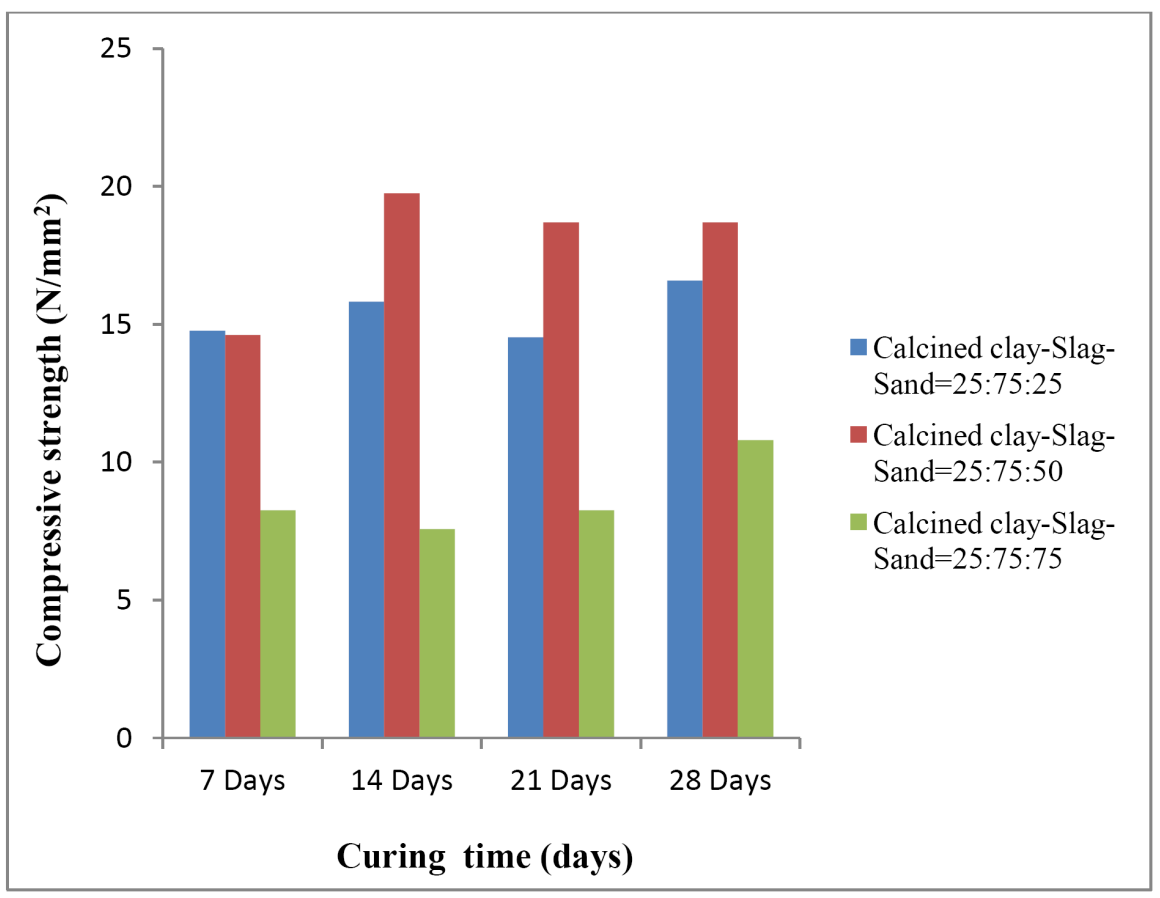

Figure 5. Compressive strength of geopolymer mortars. 
Table 3. ASTM specifications for different bricks ([31-34]).

\begin{tabular}{|c|c|c|c|c|}
\hline $\begin{array}{l}\text { Title of } \\
\text { Specification }\end{array}$ & $\begin{array}{l}\text { ASTM } \\
\text { designation }\end{array}$ & Grade & $\begin{array}{l}\text { Minimum } \\
\text { compressive } \\
\text { strength } \\
\text { (MPa) }\end{array}$ & $\begin{array}{l}\text { Maximum } \\
\text { water } \\
\text { absorption } \\
(\%)\end{array}$ \\
\hline
\end{tabular}

$\begin{array}{lllll}\text { Structural } & \text { C34-17 } & \text { LBX }^{\mathrm{A}} & 9.6^{\mathrm{C}} & 16 \\ \text { Clay Load } & & \mathrm{LB}^{\mathrm{X}} & 4.8^{\mathrm{D}} & 16 \\ \text { Bearing Wall } & & \mathrm{LB}^{\mathrm{B}} & 6.8^{\mathrm{C}} & 25 \\ \text { Tile } & \mathrm{LB} & 4.8^{\mathrm{D}} & 25\end{array}$

\begin{tabular}{|c|c|c|c|c|}
\hline Building & C62-17 & $\mathrm{SW}^{\mathrm{E}}$ & 20.7 & 17 \\
\hline \multirow[t]{2}{*}{ Brick } & & $\mathrm{MW}^{\mathrm{F}}$ & 17.2 & 22 \\
\hline & & $\mathrm{NW}^{\mathrm{G}}$ & 10.3 & No limit \\
\hline
\end{tabular}

\begin{tabular}{lllll}
\hline Facing Brick & C216-17a & SW & 20.7 & 17 \\
& & MW & 17.2 & 22 \\
\hline
\end{tabular}

$\mathrm{LBX}^{\mathrm{A}}$ - Load bearing exposed to weathering

$\mathrm{LB}^{\mathrm{B}}$ - Load bearing not exposed

C- End construction use

D- Side construction use

E- Severe weathering

G- Moderate weathering

H- Negligible weathering

\subsubsection{Water absorption and bulk density of geopolymer products}

The water absorption results for geopolymer binders cured for 28 days at ambient temperature are shown in Table 4. Geopolymer binder consisting of $100 \%$ calcined clay showed the highest percentage of water absorption capacity of $2.31 \%$ hence higher porosity, while geopolymer binder with $75 \%$ slag replacement had the lowest water absorption capacity of $1.12 \%$ due to lower void spaces in the binder. 
The water absorption results of Ijero-Ekiti calcined clay-slag-river sand geopolymer mortars at 28 days are presented in Table 5. Water absorption values decreased with increase in sand replacement. Geopolymer mortar with $25 \%$ sand replacement had the highest water absorption value of $1.53 \%$, while water absorption value of $75 \%$ sand replacement was lowered to $0.33 \%$. The water absorption values of the geopolymer mortars were much lower than the limit for ASTM C34-17, ASTM C62-17 and ASTM C21617a [31-33] in Table 3. Water absorption is an important parameter in the control of geopolymer durability. The ability of water to penetrate into a geopolymer mortar will affect its durability. The lower the water absorbed by geopolymer mortar, the higher its resistance to water penetration, hence minimising loss in compressive strength of the mortar [35].

The bulk density values of the geopolymer binders are presented in Table 4 . The bulk density value of geopolymer binder consisting of $100 \%$ calcined clay gave the lowest value of $1807 \pm 20.8 \mathrm{~kg} / \mathrm{m}^{3}$, while geopolymer binder with mix ratio, $25 \%$ calcined clay and $75 \%$ slag gave the highest bulk density value of $2037 \pm 28.9 \mathrm{~kg} / \mathrm{m}^{3}$. The bulk density values correlated inversely with water absorption values. The density of the geopolymer binders increased with increase in slag content suggesting that the microstructure of the geopolymer binders became more ordered. The bulk density values of the geopolymer mortars are presented in Table 5. Geopolymer mortar with $25 \%$ sand replacement had a density of $2145 \pm 97.8 \mathrm{~kg} / \mathrm{m}^{3}$, while the geopolymer mortar of $50 \%$ sand replacement had a density of $2205 \pm 36.0 \mathrm{~kg} / \mathrm{m}^{3}$. Finally the geopolymer mortar with $75 \%$ sand replacement gave a density value of $2112 \pm 23.6 \mathrm{~kg} / \mathrm{m}^{3}$. The density of the geopolymer mortars produced contributed favourably to the compressive strength of the mortars, as presented in Figure 5.

Table 4. Water absorption and bulk densities of geopolymer binders.

Geopolymer Specimen
Percentage Water

Absorption Capacity \pm SD

(\%)

\begin{tabular}{ccc}
\hline 100\% calcined clay & $2.31 \pm 0.15$ & $1807 \pm 20.8$ \\
$75 \%$ Calcined clay 25\% Slag & $1.16 \pm 0.15$ & $1963 \pm 20.8$ \\
$50 \%$ Calcined clay 50\% Slag & $1.45 \pm 0.08$ & $1950 \pm 10$ \\
$25 \%$ Calcined clay 75\% Slag & $1.12 \pm 0.16$ & $2037 \pm 28.9$ \\
\hline
\end{tabular}

Bulk Density \pm SD $\left(\mathrm{kg} / \mathrm{m}^{3}\right)$ 
Table 5. Water absorption and bulk densities of geopolymer mortars.

Geopolymer Specimen

\begin{tabular}{lcc} 
& $\begin{array}{c}\text { Absorption Capacity } \pm \text { SD } \\
(\%)\end{array}$ & $\left(\mathbf{k g} / \mathbf{m}^{\mathbf{3}}\right)$ \\
\hline $\begin{array}{c}\text { 25\% Calcined clay 75\% Slag } \\
\text { 25\% River sand }\end{array}$ & $1.53 \pm 0.14$ & $2145 \pm 97.8$ \\
25\% Calcined clay 75\% Slag \\
$\begin{array}{c}\text { 50\% River sand } \\
\text { 25\% Calcined clay 75\% Slag } \\
\text { 75\% River sand }\end{array}$ & $0.55 \pm 0.14$ & $2205 \pm 36.0$ \\
\hline
\end{tabular}

\subsubsection{Structural characterisation of geopolymer products}

The FTIR spectra and band positions of the geopolymer binder is presented in Figures 6-9 and Table 6. Characteristic bands of $3468 \mathrm{~cm}^{-1}$ and $1654.1 \mathrm{~cm}^{-1}$ corresponding to adsorbed atmospheric water were identified in FTIR spectrum of $100 \%$ calcined clay geopolymer. Si-O stretching vibration in $25 \%$ clay and $75 \%$ slag based geopolymer binder observed at $1008 \mathrm{~cm}^{-1}$ is lower in wave number than in calcined clay at $1022 \mathrm{~cm}^{-1}$ in Figure 6 and Figure 9. The prominent band at $1067 \mathrm{~cm}^{-1}$ in calcined clay attributed to Si-O stretching vibration shifted to lower wave number as the slag content of the geopolymer binder increased as seen in Figure 2 and Figures 7-9. The trend decreased from $75 \%$ calcined clay and $25 \%$ slag geopolymer, $50 \%$ calcined clay and $50 \%$ slag geopolymer and $25 \%$ calcined clay and $75 \%$ slag geopolymer.

According to Table $6,1067 \mathrm{~cm}^{-1}$ band in the calcined clay FTIR spectra is attributed to symmetrical vibration of Si-O bond, while $1008 \mathrm{~cm}^{-1}$ band in FTIR spectra of $25 \%$ clay and $75 \%$ slag based geopolymer is caused by asymmetrical vibration of the $\mathrm{Si}-\mathrm{O}$ bond. The shift towards low wave number may be attributed to partial replacement of $\mathrm{SiO} 4$ tetrahedron by $\mathrm{AlO} 4$ tetrahedron resulting in a change in the local environment of the Si-O bond. 


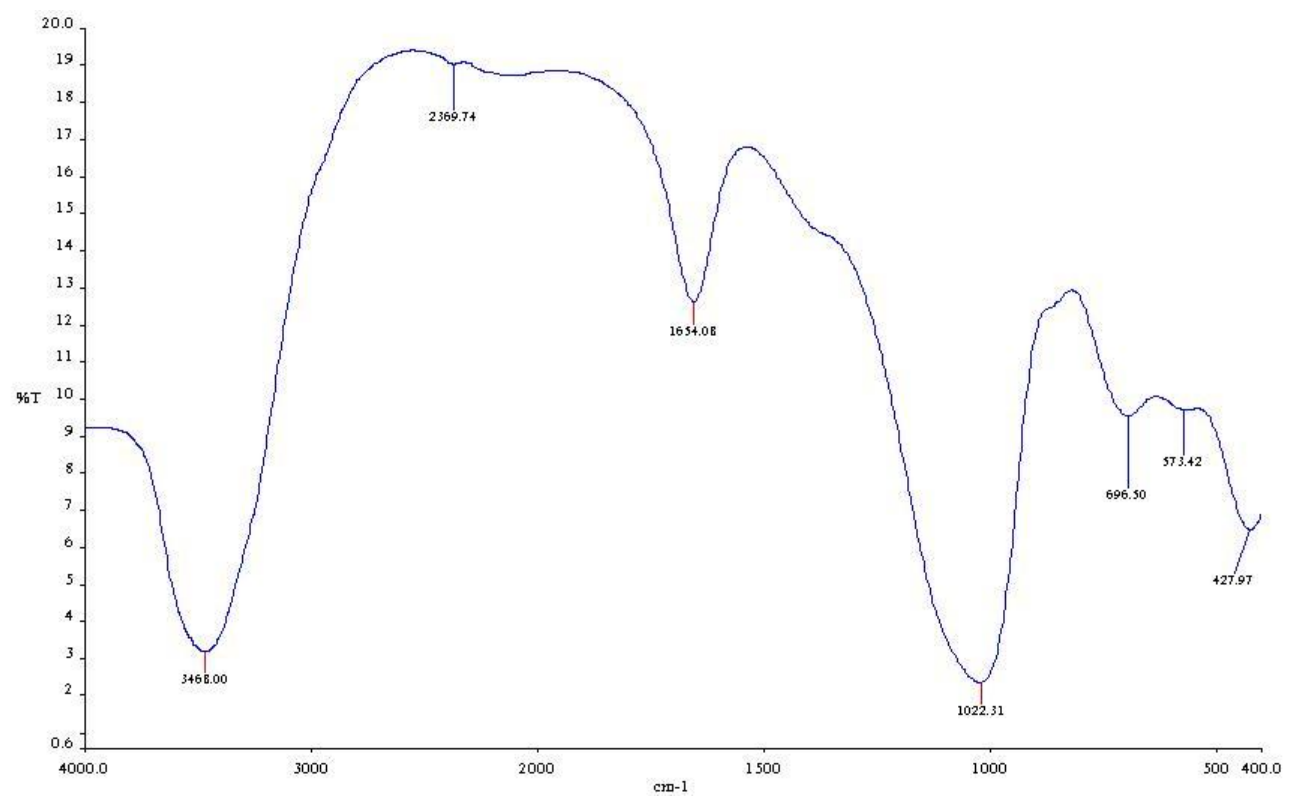

Figure 6. FTIR spectrum of 100\% Ijero-Ekiti calcined clay geopolymer [23].

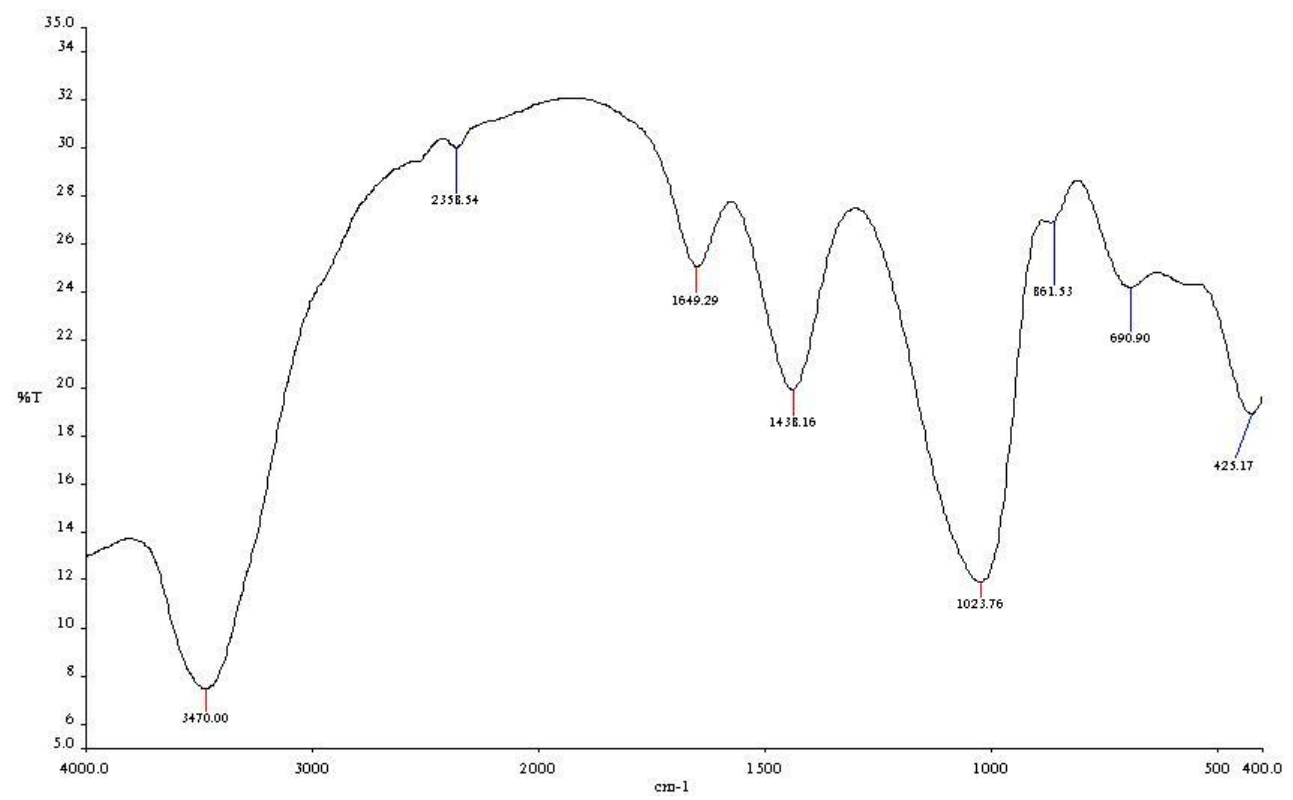

Figure 7. FTIR spectrum of $75 \%$ Ijero-Ekiti calcined clay and $25 \%$ slag geopolymer binder. 


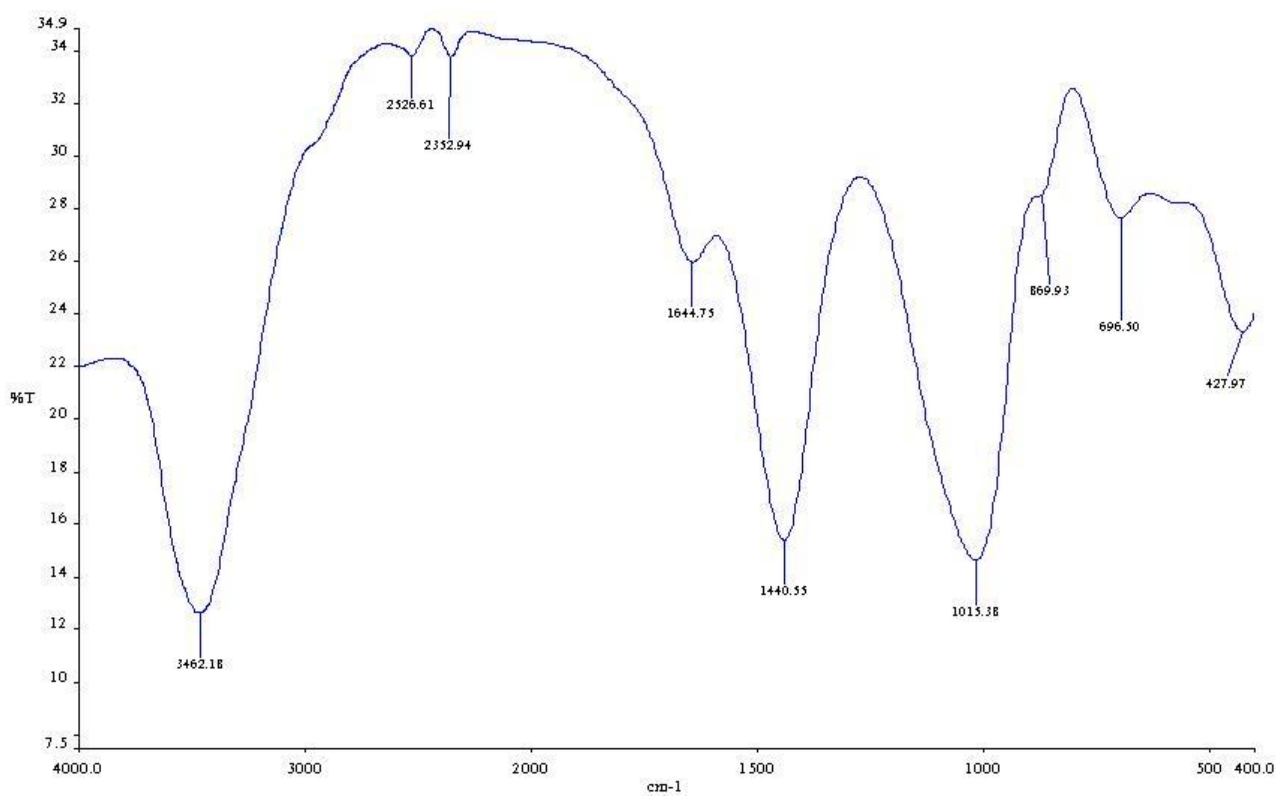

Figure 8. FTIR spectrum of 50\% Ijero-Ekiti calcined clay and 50\% slag geopolymer binder.

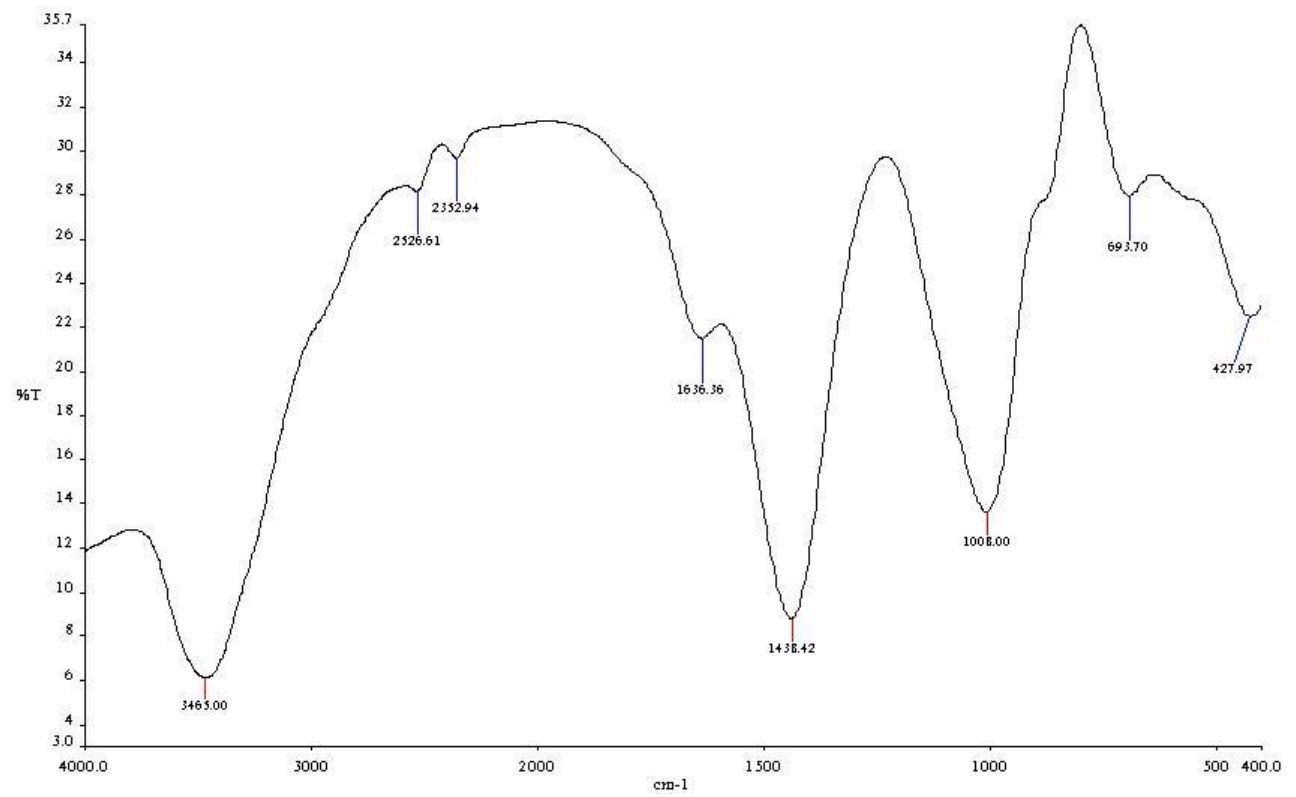

Figure 9. FTIR spectrum of 25\% Ijero-Ekiti calcined clay and $75 \%$ slag geopolymer binder. 
Table 6. Infrared band positions of the studied source materials and the corresponding geopolymers.

\begin{tabular}{|c|c|c|c|c|c|c|c|c|}
\hline $\begin{array}{l}\text { Raw } \\
\text { clay }\end{array}$ & $\begin{array}{l}\text { Calcined } \\
\text { clay }\end{array}$ & Slag & $\begin{array}{l}\text { River } \\
\text { sand }\end{array}$ & $\begin{array}{l}100 \% \\
\mathrm{CC}\end{array}$ & $\begin{array}{l}75 \% \mathrm{CC} \text { and } \\
25 \% \mathrm{~S}\end{array}$ & $\begin{array}{l}50 \% \mathrm{CC} \text { and } \\
50 \% \mathrm{~S}\end{array}$ & $\begin{array}{l}25 \% \mathrm{CC} \text { and } \\
75 \% \mathrm{~S}\end{array}$ & Assignment \\
\hline 3652 & & & & & & & & $\begin{array}{l}\text { OH stretching of inner } \\
\text { surface hydroxyl groups. }\end{array}$ \\
\hline 3473 & 3467 & 3445 & 3458 & 3468 & 3470 & 3462 & 3465 & $\mathrm{H}-\mathrm{O}-\mathrm{H}$ stretching \\
\hline - & 2936 & 2947 & 2936 & - & - & - & - & C-H stretching vibration \\
\hline- & - & 2885 & - & - & - & - & - & Carbon in calcite \\
\hline- & - & 2521 & - & - & - & 2526 & 2527 & \\
\hline- & - & 2381 & - & 2370 & 2358 & 2353 & 2353 & \\
\hline 1638 & 1639 & - & 1636 & 1654 & 1649 & 1645 & 1636 & H-O-H stretching \\
\hline - & - & 1435 & - & - & 1438 & 1441 & 1438 & $\begin{array}{l}\mathrm{CO}\left(\mathrm{CO}_{32}-\right) \text { asymmetric } \\
\text { stretching vibration }\end{array}$ \\
\hline 1040 & 1067 & 1038 & 1065 & 1022 & 1024 & 1015 & 1008 & $\mathrm{Si}-\mathrm{O}$ stretching vibration \\
\hline 923 & - & - & - & - & - & - & - & $\begin{array}{l}\text { Al-O-H stretching } \\
\text { vibration }\end{array}$ \\
\hline - & 808 & - & - & - & - & - & - & $\begin{array}{l}\text { Al-O-H stretching } \\
\text { vibration }\end{array}$ \\
\hline - & - & 872 & - & - & 861 & 870 & - & $\begin{array}{l}\mathrm{CO}\left(\mathrm{CO}_{32}-\right) \text { asymmetric } \\
\text { bending vibration }\end{array}$ \\
\hline- & - & - & 766 & - & - & - & - & $\mathrm{Si}-\mathrm{O}$ quartz \\
\hline 660 & 663 & 694 & - & 697 & 691 & 667 & 694 & $\mathrm{Si}-\mathrm{O}$ quartz \\
\hline 550 & 554 & - & - & 573 & - & - & - & Si-O quartz \\
\hline 436 & 439 & - & 442 & 428 & 425 & 428 & 428 & $\begin{array}{l}\text { Si-O quartz, Si-O bending } \\
\text { vibration }\end{array}$ \\
\hline
\end{tabular}

[24-25, 36-37]. 


\section{Conclusion}

The XRF result showed that the silica and alumina oxides are present in major quantities in the Ijero-Ekiti calcined clay making it suitable as a geopolymer source material. The addition of blast furnace slag to the calcined clay improved the water absorption, bulk density and compressive strength of the resultant geopolymer binders.

The geopolymer mortar with 50\% sand replacement exhibited the highest compressive strength of $18.7 \pm 0.32 \mathrm{~N} / \mathrm{mm}^{2}$. Consequently, the results confirmed the combination of Ijero-Ekiti calcined clay with blast furnace slag as a greener alternative to Portland cement.

\section{References}

[1] C. Robert, Concrete Planet: The Strange and Fascinating Story of the World's Most Common Man-Made Material, Prometheus Books, Amherst, N.Y., 2011. Retrieved 28 August, 2015.

[2] R. McCaffrey, Climate change and the cement industry, Global Cement and Lime Magazine (Environmental Special Issue) (2002), 15-19.

[3] J. Davidovits, Properties of geopolymer cements, Proc. First International Conference on Alkaline Cements and Concretes, 1994, pp. 131-149.

[4] J. Davidovits, ed., Geopolymer Chemistry and Applications, 2nd ed., Institut Géopolymère, Saint-Quentin, France, 2008.

[5] M. B. Ogundiran and S. Kumar, Synthesis and characterisation of geopolymer from Nigerian Clay, Applied Clay Science 108 (2015), 17-181.

https://doi.org/10.1016/j.clay.2015.02.022

[6] T. W. Cheng, M. L. Lee, M. S. Ko, T. H. Ueng and S. F. Yang, The heavy metal adsorption characteristics on metakaolin-based geopolymer, Applied Clay Science 56 (2012), 90-96. https://doi.org/10.1016/j.clay.2011.11.027

[7] M. A. Soleimani, R. Naghizadeh, A. R. Mirhabibi and F. Golestanifard, Effect of calcination temperature of the kaolin and molar $\mathrm{Na}_{2} \mathrm{O} / \mathrm{SiO}_{2}$ activator ratio on physical and microstructural properties of metakaolin based geopolymers 2012, Iranian Journal of Materials Science \& Engineering 9(4) (2012).

[8] C. Kuenzel, T. P. Neville, S. Donatello, L. Vandeperre, A. R. Boccaccini and C. R. Cheeseman, Influence of metakaolin characteristics on the mechanical properties of 
geopolymers, Applied Clay Science 83-84 (2013), 308-314.

https://doi.org/10.1016/j.clay.2013.08.023

[9] B. B. Kenne Diffo, A. Elimbi, M. Cyr, J. Dika Manga and H. Tchakoute Kouamo, Effect of the rate of calcinations of kaolin on the properties of metakaolin-based geopolymers, Journal of Asian Ceramic Societies 3 (2014), 130-138.

https://doi.org/10.1016/j.jascer.2014.12.003

[10] M. Sarker, K. Dana and S. Das, Microstructural and phase evolution in metakaolin geopolymers with different activators and added aluminosilicate fillers, Journal of Molecular Structure 1098 (2015), 110-118.

https://doi.org/10.1016/j.molstruc.2015.05.046

[11] J. Davidovits, ed., Geopolymer Chemistry and Applications, 4th ed., Institut Géopolymère, Saint-Quentin, France, 2015.

[12] T. W. Cheng and J. P. Chiu, Fire-resistant geopolymer produced by granulated blast furnace slag, Minerals Engineering 16 (2003), 205-210.

https://doi.org/10.1016/S0892-6875(03)00008-6

[13] A. Dubey, R. Chandak and R. K. Yadav, Effect of blast furnace slag powder on compressive strength of concrete, International Journal of Scientific and Engineering Research 3(8) (2012).

[14] C. Li, H. Sun and L. Li, A review: The comparison between alkali-activated slag ( $\mathrm{Si}+\mathrm{Ca})$ and metakaolin ( $\mathrm{Si}+\mathrm{Al})$ cements, Cement and Concrete Research 40 (2010), 1341-1349. https://doi.org/10.1016/j.cemconres.2010.03.020

[15] Z. Li and Z. Ding, Property improvement of Portland cement by incorporating with metakaolin and slag, Cement and Concrete Research 33 (2003), 579-584. https://doi.org/10.1016/S0008-8846(02)01025-6

[16] B. O'Rourke, C. McNally and M. G. Richardson, Development of calcium sulfate-ggbsPortland cement binders, Construction and Building Materials 23 (2009), 340-346. https://doi.org/10.1016/j.conbuildmat.2007.11.016

[17] P. S. Deb, P. Nath and P. K. Sarker, The effects of ground granulated blast-furnace slag blending with flyash and activator content on the workability and strength properties of geopolymer concrete cured at ambient temperature, Materials and Design 62 (2014), 32-39. https://doi.org/10.1016/j.matdes.2014.05.001

[18] X. Huang, L. Yu, D. W. Li, Y. C. Shiau, S. Li and K. X. Liu, Preparation and properties of geopolymer from blast furnace slag, Materials Research Innovations 19 (2015), 413419. https://doi.org/10.1179/1432891715Z.0000000002210 
[19] C. K. Yip, G. C. Lukey and J. S. J. Van Deventer, Microstructure and properties of slag/metakaolinite geopolymeric materials, 28th Conference on Our World in Concrete \& Structures, Singapore, 2003.

[20] G. F. Huseien, J. Mirza, M. Ismail, S. K. Ghoshal and Mohd Azreen Mohd Ariffin, Effect of metakaolin replaced granulated blast furnace slag on fresh and early strength properties of geopolymer mortar, Ain Shams Engineering Journal 9 (2018), 1557-1566. https://doi.org/10.1016/j.asej.2016.11.011

[21] O. Burciaga-Diaz, L. Y. Gomez-Zamorano and J. I. Escalante-Garcia, Influence of long term curing temperature on the hydration of alkaline binders of blast furnace slagmetakaolin, Construction and Building Materials 113 (2016), 917-926.

https://doi.org/10.1016/j.conbuildmat.2016.03.111

[22] P. H. R. Borges, N. Banthia, H. A. Alcamand, W. L. Vasconcelos and E. H. M. Nunes, Performance of blended metakaolin/blast furnace slag alkali-activated mortars, Cement and Concrete Composites 71 (2016), 42-52. https://doi.org/10.1016/j.cemconcomp.2016.04.008

[23] M. B. Ogundiran and F. A. Winjobi, The potential of binary blended geopolymer binder containing Ijero-Ekiti calcined kaolin clay and ground waste window glass, African Journal of Pure and Applied Chemistry 9(7) (2015), 159-166.

https://doi.org/10.5897/AJPAC2015.0640

[24] P. Djomgoue and D. Njopwouo, FT-IR spectroscopy applied for surface clays characterization, Journal of Surface Engineered Materials and Advanced Technology 3 (2013), 275-282. https://doi.org/10.4236/jsemat.2013.34037

[25] V. F. F. Barbosa, K. J. D. Mackenzie and C. Thaumaturgo, Synthesis and characterisation of materials based on inorganic polymers of alumina and silica: sodium polysialate polymers, International Journal of Inorganic Materials 2 (2000), 309-317.

https://doi.org/10.1016/S1466-6049(00)00041-6

[26] J. Davidovits, ed., Geopolymer Chemistry and Applications, 3rd ed., Institut Géopolymère, Saint-Quentin, France, 2011.

[27] A. R. Sakulich, S. Miller and M. W. Barsoum, Chemical and microstructural characterization of 20-month-old alkali-activated slag cements, J. Am. Ceram. Soc. 93(6) (2010), 1741-1748. https://doi.org/10.1111/j.1551-2916.2010.03611.x

[28] L. Blahova, M. Mucha, Z. Navratilova and S. Gorosova, Sorption properties of slag, Journal of the Polish Mineral Engineering Society 36 (2015), 89-94.

[29] I. Ismail, S. A. Bernal, J. L. Provis, R. San Nicolas, S. Hamdan and J. S. J. Van Deventer, 
Modification of phase evolution in alkali-activated blast furnace slag by the incorporation of fly ash, Cement and Concrete Composites 45 (2014), 125-135.

https://doi.org/10.1016/j.cemconcomp.2013.09.006

[30] J. He, Synthesis and characterisation of geopolymers for infrastructural applications, 2012. Retrieved December 29, 2017, from https://digitalcommons.lsu.edu/cgi/view content.cgi?referer=https://scholar.google.co.in/\&httpsredir=1\&article=1163\&context=gr adschool_dissertations

[31] ASTM standard C34-17, Standard specification for structural clay load bearing wall tile, ASTM International, West Conshohocken, PA, 2017. www.astm.org

[32] ASTM standard C62-17, Standard specification for building brick (solid masonry units made from clay to shale), ASTM International, West Conshohocken, PA, 2017. www.astm.org

[33] ASTM standard C216-17a, Standard specification for facing brick (solid masonry units made from clay or shale), ASTM International, West Conshohocken, PA, 2017. www.astm.org

[34] S. Ahmari and L. Zhang, Production of eco-friendly bricks from copper mine tailings through geopolymerisation, Construction and Building Materials 29 (2011), 323-331. https://doi.org/10.1016/j.conbuildmat.2011.10.048

[35] Q. Mohsen and N. Y. Mostafa, Investigating the possibility of utilizing low kaolinitic clays in production of geopolymer bricks, Ceramics - Silikáty 54(2) (2010), 160-168.

[36] J. S. Bhasker and P. Gopalakrishnarao, Fourier transform infrared spectroscopic characterization of kaolinite from Assam and Meghalaya, Northeastern India, J. Mod. Phys. 1 (2010), 206-210. https://doi.org/10.4236/jmp.2010.14031

[37] H. M. Van der Marel and H. Beutelspacher, Atlas of Infrared Spectroscopy of Clay Minerals and Their Admixtures, Elsevier Science Publishers, New York, 1976. 